Article

\title{
Development of Full-Cycle Utilization of Chlorella sorokiniana Microalgae Biomass for Environmental and Food Purposes
}

\author{
Natalia Politaeva ${ }^{1, *(D)}$, Yulia Smyatskaya ${ }^{1}\left(\mathbb{D}\right.$, Rafat Al Afif $^{2}$, Christoph Pfeifer $^{3}(\mathbb{D}$ \\ and Liliya Mukhametova ${ }^{4}$ \\ 1 Department of Institute of Civil Engineering, Peter the Great Sankt-Petersburg Polytechnic University, \\ 194064 Saint Petersburg, Russia; makarovayulia169@mail.ru \\ 2 Department of Material Sciences and Process, Institute of Chemical and Energy Engineering, \\ Vienna Engineering, University of Natural Resources and Life Sciences, 1190 Vienna, Austria; \\ rafat.alafif@boku.ac.at \\ 3 Department of Material Sciences and Process Engineering, Vienna Institute of Chemical and Energy \\ Engineering, University of Natural Resources and Life Sciences, 1190 Vienna, Austria; \\ christoph.pfeifer@boku.ac.at \\ 4 Department of Economics and Organization Production, Kazan State Power Engineering University, \\ 420066 Kazan, Russia; liliymyhametova@mail.ru \\ * Correspondence: politaevana1971@gmail.com; Tel.: +7-921-868-65-54
}

Received: 12 April 2020; Accepted: 19 May 2020; Published: 22 May 2020

\begin{abstract}
The application of microalgae biomass of Chlorella sorokiniana as environmentally friendly biosorbents for removing potentially toxic elements (PTE) from water and as a source of biofuel has been thoroughly studied. In this paper, we investigate its physicochemical properties infrared spectroscopy (IR spectra), microstructure, adsorption properties); we have managed to isolate the lipid complex, which amounted to $20 \%$ of dry biomass. Studies of the lipid complex showed that $80.02 \%$ of lipids are unsaturated fatty acids (C18:1, C18:2, C18:3). Additionally, we have investigated the efficiency of using the residual biomass obtained after lipid extraction for water purification from rare-earth metals (REM) and PTE. To increase the sorption properties of residual biomass, its thermal modification was carried out and sorption materials based on heat-treated residual biomass and chitosan were created. The physicochemical and mechanical properties of the obtained sorption materials were studied. The total sorption capacity was $31.9 \mathrm{mg} / \mathrm{g}$ for REM and $349.7 \mathrm{mg} / \mathrm{g}$ for PTE. Moreover, we propose a new method for the disposal of spent sorbents as additional fuel. Spent sorbents can be considered to be biofuel in terms of energy content $\left(20.7 \mathrm{MJ}^{*} \mathrm{~kg}^{-1}\right)$. The results of this study provide the basis for increased use of microalgae.
\end{abstract}

Keywords: microalgae; sorbents; water purification; REM; PTE; lipids; Omega-3; biofuel

\section{Introduction}

Sustainable biomass-based fuels produced through transesterification [1,2], anaerobic digestion and fermentation [3-7], extraction [8,9], hydrothermal carbonization [10-13], pyrolysis [14-19], gasification [20-23], liquefaction processes [24-26] are excellent alternative fuels and can play an important role in reducing the formation of greenhouse gases and acid rain.

Over the past decade, many researchers have proposed algae and microalgae as raw materials for biofuel production, however, their use is associated with a number of problems, mainly due to the high water content in algae and microalgae [27]. As microalgae have rather distinct properties in comparison with other biomass types and such differences have a more positive eco-technology impact during the 
utilization of microalgae and their conversion products, simultaneously producing biomaterials and products for bio-remediation seems to be a promising avenue [28-30]. Numerous reviews of utilization of algae and microalgae in biorefinery concepts are available [31,32]. Nowadays, microalgae are widely used in a variety of ways. Having rich vitamin and protein composition, microalgae are utilized for livestock feed and even as human food [33-36]. The authors in the articles [37-39] described various applications of microalgae for medical and environmental purposes. An interesting scientific approach is obtaining a variety of valuable components from microalgae, namely:

1. Lipids, which, depending on the fatty acid composition, can be sources of Omega-3, Omega-6 [40] or biofuel;

2. Biosorbents for metal biomining;

3. Enterosorbents for detoxification.

Ways and methods for obtaining lipids from algae have been studied by scientists around the world. American scientists [41] have investigated three strains of C. sorokiniana species and developed a lipid extraction technique. Chader et al. [42,43] cultivated Chlorella for subsequent production of biofuels. Its biomass was centrifuged, dried to constant weight, and lyophilized. The gas chromatographic method was used to determine the composition of fatty acids. The results showed that a mixture of unsaturated fatty acids consisted of oleic (18:1), linoleic (18:2) and linolenic (18:3) acids; saturated fatty acids, namely, palmitic (16:0) and stearic (18:0), were also present to a small extent. Palmitic, stearic, oleic and linoleic acids are the most common fatty acids contained in biodiesel. In laboratory conditions, Blinová [10] obtained biofuel for diesel engines from C. Vulgaris. The influence of growth conditions on the properties of biodiesel was evaluated, and the properties of the resulting biofuels were found to comply with ASTM (American Society for Testing and Materials) standards.

At the same time, growing global demand for rare-earth metals (REM) has led to a shortage of primary resources. Nowadays, traditional REM extraction processes are energy-consuming and not environmentally friendly due to the use of various toxic chemicals.

REM and potentially toxic elements (PTE) are used in various industries. Obtaining REM materials from secondary (waste) instead of from primary (natural) resources is of great current interest. The problem of wastewater treatment with regard to PTE and REM is relevant worldwide [44]. The main sources of these contaminations are waste from mining and processing enterprises and effluents from industrial companies, chiefly metal processing. Biomining is a new technology that uses biological systems to extract metals from liquid media. This technology has been studied until now only for copper, nickel and gold. Biochemical mechanisms, including biomining of primary minerals, are used in articles [45,46]. Studies on the recovery of metals from secondary sources using the concept of biomining have not yet been widely conducted. It can be applied to processing wastewater and discarded electronic equipment [47].

Sorption mechanisms include the use of dead biomass [48]. In this case, dead biomass is more flexible to environmental conditions and to various concentrations of most pollutants, including PTE and REM. Various sources of biosorbents, such as bacteria, yeast, fungi, algae, and plant biomass, can be used for sorption of metals [49]. As a rule, various biomaterials have biosorption potential for sorption of various metal ions. In preliminary works presented in articles [50,51], C. Vulgaris green microalgae were studied as a potential biosorbent for extracting neodymium from its magnetic filtrates in batch and continuous sorption systems. High metal biosorption by microalgae biomass has been achieved by some scientists [50,51], showing the concept of sorption processes and the absorption mechanism. Some functional groups have been found in algae cells that initiate the binding of metals, such as hydroxyl, carboxylate, and amino groups.

Besides C. Vulgaris, C. Sorokiniana is widely used for metal extraction. Sorption of PTE (copper, nickel, cadmium) from drinking water by C. Sorokiniana, immobilized on an extract from Laminaria algae was studied in articles [52]. The sorption process was studied in the range of initial concentrations 5-350 $\mathrm{mg} / \mathrm{l}$ and the $\mathrm{pH}$ was 3-7. 
In the article [53], C. Sorokiniana cells immobilized in loofa sponge were used to extract chromium ions. A loofa sponge was prepared by boiling in distilled water, followed by washing. The introduction of microalgae was carried out within 24 days. Subsequently, the samples were used to extract chromium ions from model solutions. The extraction efficiency for chromium (III) ions was $98 \%$, the sorption capacity was $69.9 \mathrm{mg} / \mathrm{g}$. The possibility of its reuse, at least for 5 cycles, is proven. Thanks to the ease of use, the problem of the possibility of using biosorbent on an industrial scale has been solved.

The processes of chromium (III) sorption using green algae were studied by the authors of [54]. The metal removal was carried out using specially prepared granules with a diameter of several millimetres, which consisted of a polymer base and some powder of C. Vulgaris or S. Acutus included in it.

Representatives of the genus Chlorella often enter into symbiotic relationships with various fungi species. In the article [55], the microalga C. Vulgaris UMN235 and two locally isolated species of fungi Aspergillus sp. UMN F01 and UMN F02 were used to study the influence of various conditions on the granulation of the mushroom-algal complex. The results showed that $\mathrm{pH}$ is the key factor affecting granule formation, and it can be controlled by changing glucose concentration and adding fungal spores. The obtained technology allows for simplifying the algae harvesting process and increasing wastewater treatment efficiency.

It is not economically viable to use the original microalgae biomass, because it contains a large amount of fatty acids, which are part of biofuels and Omega-3.

The authors hypothesize the possibility of cascading the use of microalgae for environmental and food purposes, at the first stage isolating lipid fractions for biofuel and Omega-3, and at the second stage using residual biomass as sorbents for water purification from REM and PTE.

\section{Materials and Methods}

\subsection{Cultivation of Microalgae Biomass}

To obtain the microalgae biomass, we used 8 closed photobioreactors with a volume of 30 litres each (Figure 1a), which allowed us to cultivate biomass in natural conditions, and a closed photobioreactor with a volume of 90 litres (Figure 1b,c) for laboratory conditions.

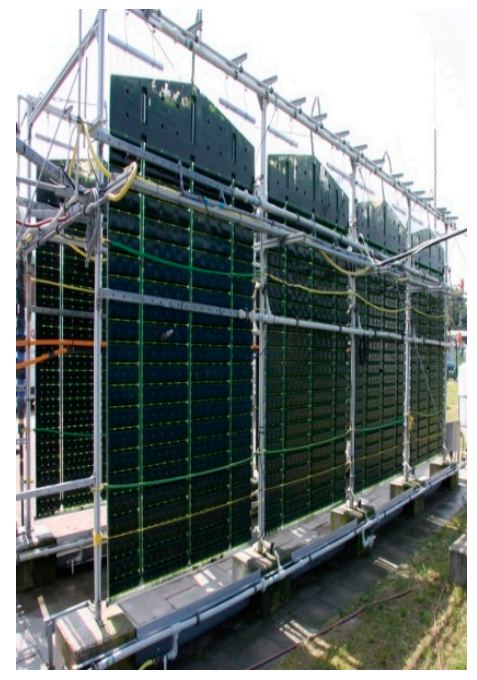

(a)

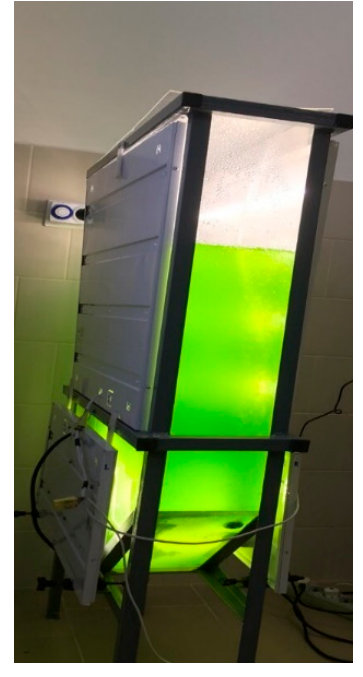

(b)

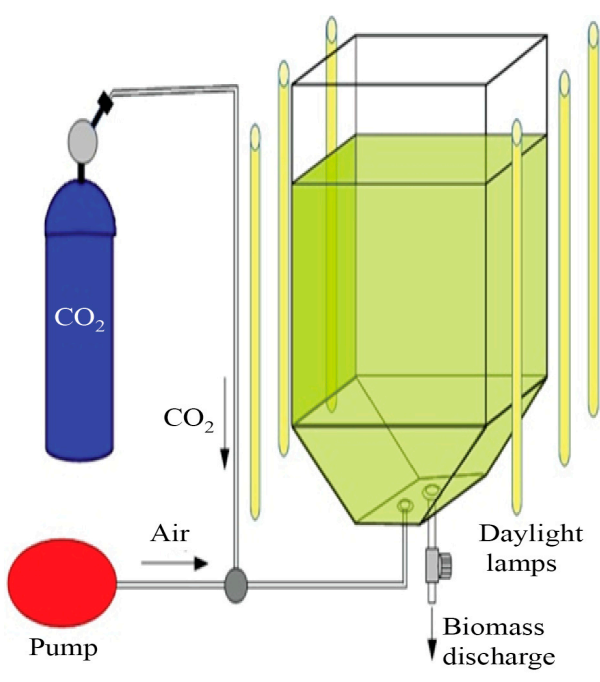

(c)

Figure 1. Closed photobioreactors for C. Sorokiniana microalgae biomass cultivation: (a) for cultivation under natural conditions, (b) for cultivation under laboratory conditions, (c) photobioreactor scheme. 
To obtain biomass from growth of microalgae, C. Sorokiniana was cultivated, concentrated and dried. To obtain the maximum amount of C. Sorokiniana biomass in our laboratory, the following conditions were maintained: $\mathrm{pH}=8.0 \pm 0.5$; light intensity of $2500 \pm 300 \mathrm{Lx}$; temperature of $28 \pm 2{ }^{\circ} \mathrm{C}$; aeration not less than $1.5 \mathrm{l} / \mathrm{min}$ and the cultivation time of 10 days.

Biomass growth was monitored by optical density using a spectrophotometer Shimadzu UV- 1208 . Cell counting was performed using a Goryev's camera. Under natural conditions, it is rational to cultivate algae from mid-April to mid-October, i.e., the cultivation period is 6 months per year.

\subsection{Obtaining Dry Biomass}

For lipid extraction processes, it is necessary to use dry microalgae biomass. For this, microalgae suspension was concentrated and dried.

Concentrations were carried out using a $12 \mathrm{~L}$ centrifuge, Avanti J-30i Beckman Coulter, with a cooling system. Centrifugation speed was $30,000 \mathrm{rpm}$. The resulting thick paste (moisture content up to $40 \%$ ) was dried by the lyophilic method, within which the paste was first frozen at $\mathrm{T}=-20^{\circ} \mathrm{C}$ and then lyophilized at a pressure of $1 \mathrm{mbar}\left(-20^{\circ} \mathrm{C}\right)$ at an ice condenser temperature of $-55^{\circ} \mathrm{C}$ using the Alpha 1-2 LDplus lyophilization device from Martin Christ Gefriertrocknungsanlagen GmbH.

\subsection{Determination of Specific Surface Area}

The specific surface area of materials was determined by low-temperature nitrogen adsorption $\left(-196^{\circ} \mathrm{C}\right)$ using the BET (Brunauer, Emmett and Teller) method on the TriStar II 3020 automated sorption installation from Micromeritics (USA). The volumetric version of the sorption method was used.

\subsection{IR Spectra}

The IR spectra of the residual biomass and sorbents were recorded using the FSM 1201 spectrometer. $\mathrm{A} \mathrm{KBr}$ tablet obtained by pressing its crystalline powder during vacuum pumping was used as a reference sample. Samples were obtained by pressing a mixture of the test powder $(5 \mathrm{mg})$ and $\mathrm{KBr}$. The total weight of the tablet with the test sample was $300 \mathrm{mg}$.

\subsection{Lipid Extraction and Determination of Their Composition}

The lipid fraction extraction from C. sorokiniana microalgae biomass was carried out on the Büchi E-812 SOX Soxhlet apparatus. For this, $3 \mathrm{~g}$ of dry biomass was placed in a cellulose glass $(33 \mathrm{~mm} \times 94 \mathrm{~mm})$. A mixture of ethanol and $\mathrm{n}$-hexane (1:9), was used as an extractant. For $3 \mathrm{~g}$ of dry biomass, $100 \mathrm{ml}$ of extractant was used. We studied and established the optimal extraction parameters for the maximum lipid yield (20\%): the extraction time of 3.5 hours; hexane and ethanol (9:1) used as an extractant; 10 cycles of extraction. The qualitative composition of total lipids obtained from the biomass of C. Sorokiniana microalgae was investigated by thin layer chromatography (TLC) using PTCX-AF-B plates. Plate analysis was performed using the Sorbfil densitometer and Sorbfil TLC software (Version 1.0, Sorbpolimer, Krasnodar, Russia). For this, lipid samples obtained from C. Sorokiniana microalgae in the amount of $3 \mu \mathrm{l}$ were deposited to PTSX-AF-B chromatographic plates. The plate was placed in a chromatographic chamber, which was prefilled with a mixture of solvents: petroleum ether/diethyl ether/acetic acid in a ratio of 90:10:1. The plate was immersed in a solvent to the depth of 5-6 mm. The distillation was carried out for 50-60 minutes at room temperature. After this, the plate was dried and sprayed with a $30 \%$ sulfuric acid solution. Sprayed plates were kept in an oven heated to a temperature of $180{ }^{\circ} \mathrm{C}$ for 30 minutes. As a result, all lipids were charred and formed black spots. After the development of the analyzed plate, it was placed in a lighting chamber, for this it was fixed on a stage, introduced into the chamber, and illuminated with light of a selected wavelength. The plate image was stored in the computer memory using a Sony video camera; the video image was processed using the Sorbfil TLS View program. Compounds were identified using reference data on the path length. 
The composition of higher fatty acids in the lipids obtained from the C. Sorokiniana microalgae biomass was determined using the gas chromatograph with a flame ionization detector Agilent technologies sales and services $\mathrm{GmbH}$ and Co.KG, on a BPX70 column $(60 \mathrm{~m} \times 0.25 \mathrm{~mm} \times 0.25 \mu \mathrm{m})$, SGE analytical science, VWR international $\mathrm{GmbH}$; carrier gas was nitrogen.

\subsection{Microstructural Studies}

Microstructural studies were performed using scanning electron microscopy at JSM-7001F, Jeol.

\subsection{Obtaining Sorbents and Studying Their Sorption Properties}

The scheme for producing adsorbents is shown in Figure 2.

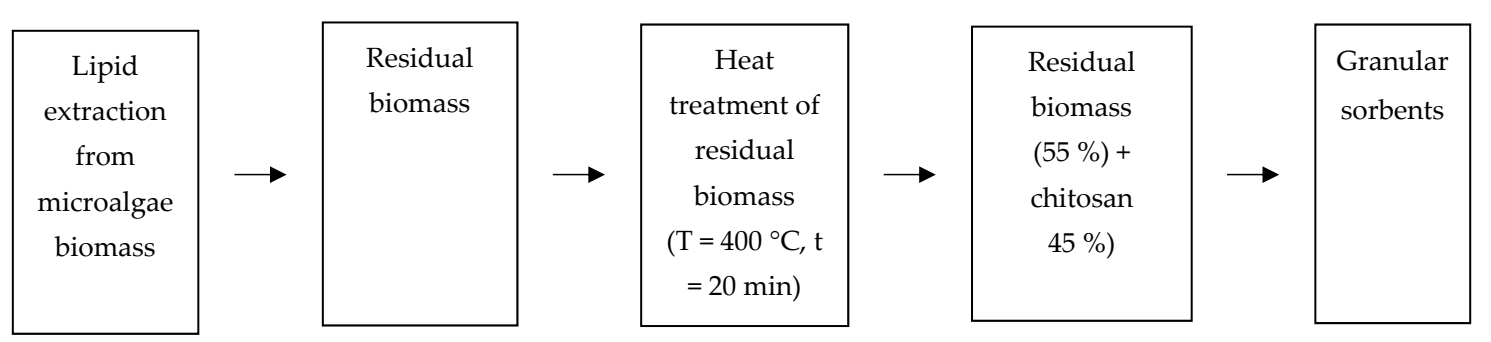

Figure 2. Experiment design.

The residual biomass was thermally treated at $\mathrm{T}=400{ }^{\circ} \mathrm{C}$ for $20 \mathrm{~min}$ in a special cell without oxygen. The obtained heat-treated residual biomass was a fine black powder. Granules were made from heat-treated powder of residual biomass by droplet granulation; the procedure is described in detail in articles [56-58]. Chitosan, which is a safe biodegradable biopolymer, was used as a binder, therefore not harming the environment. The composition of the mixture and dry granules of experimental samples of sorption material from the residual biomass of microalgae Chlorella sorokiniana is 5:95 mass \% for the mixture and 55.5:44.5 wt. \% for dry granules. Sorption properties of sorbents made of residual biomass were investigated under the conditions: ratio of sorbent mass and solution $=2 \mathrm{~g}$ per $1 \mathrm{dm}^{3}$; $\mathrm{pH}=4.0 \pm 0.2$ units of $\mathrm{pH} ; \mathrm{T}=293 \pm 2 \mathrm{~K}$. The sorption process was carried out in two stages, initially the solution with a weighed portion of the sorbent was mixed in the OS-20 laboratory shaker from Biosan (Latvia) for 2 hours at a velocity of $v=250 \mathrm{rpm}$. For the remaining time ( 22 hours), the solution was static. The required $\mathrm{pH}$ value was adjusted with $\mathrm{HNO}_{3}(7 \%)$ and $\mathrm{NaOH}(7 \%)$ solutions and controlled using a laboratory ion meter I-160MI (LLC "Measuring technique"). We used model solutions containing $\mathrm{Zn}$ (II), $\mathrm{Cd}$ (II), $\mathrm{Cu}$ (II) ions, which were prepared from $\mathrm{CuSO}_{4} \cdot 5 \mathrm{H}_{2} \mathrm{O}, \mathrm{ZnSO}_{4} \cdot 7 \mathrm{H}_{2} \mathrm{O}$ and $3 \mathrm{CdSO}_{4} \cdot 8 \mathrm{H}_{2} \mathrm{O}$ salts, and for the preparation of model solutions of REM we have used standard samples. The initial concentration of the solutions was $50 \mathrm{mg} / \mathrm{g}$. At the end of the sorption process, the sorbent mass was separated from the solution by filtration using a decalcified White Ribbon filter, and the solution was decanted after purification with sorbents. The initial and equilibrium solution concentration before and after treatment with sorbents were evaluated using the inversion voltammetry on a TA-Lab analyzer (NPP Tomanalit, Tomsk, Russia).

Studies on the extraction of REM from model solutions with various concentrations were carried out at $\mathrm{pH}=4$. Coupled Plasma-Optical Emission Spectroscopy (ICP-OES) was used to determine the concentrations in the REM solution.

The efficiency (E) of model wastewater purification was calculated according to the formula:

$$
\mathrm{E}=\frac{\mathrm{C}_{0}-\mathrm{C}_{\mathrm{t}}}{\mathrm{C}_{0}} \cdot 100 \%,
$$

where $\mathrm{C}_{0}$ and $\mathrm{Ct}$ are initial and final concentration of solution, $\mathrm{mg} / \mathrm{l}$. 
The adsorption capacity Ai of adsorbent at any given time was determined by the equation:

$$
\mathbf{A}_{\mathbf{i}}=\frac{\mathrm{C}_{0}-\mathrm{C}_{\mathrm{t}}}{\mathbf{m}} \mathrm{V}
$$

where $C_{0}$ is the initial concentration, $C t$ is the solution concentration at a given time, $\mathrm{g} / \mathrm{l} ; \mathrm{m}$ is the sorbent mass, $\mathrm{g}$; $\mathrm{V}$ is the solution volume, $\mathrm{L}$.

\subsection{Determination of Specific Heat of Combustion}

Tests for determining the higher heating value (HHV) of the spent sorbents were carried out at the laboratory of the Hamburg University of Technology (Germany) using the IKA C 5000 calorimeter. The device used is a bomb calorimeter with an adiabatic jacket in accordance with DIN EN 51900-3. The spent sorbents are predried at $45^{\circ} \mathrm{C}$ to constant weight, then crushed to $<0.25 \mathrm{~mm}$. The lower heating value LHV is calculated from the HHV.

\section{Results}

Our results show that over 10 days of cultivation, the biomass reached an optical density of 1.7, which corresponds to $43 \times 10^{6}$ cells $/ \mathrm{ml}$. When growing biomass of microalgae in a volume of $90 \mathrm{~L}$, it is possible to obtain about $54 \mathrm{~g}$ of dry biomass.

Investigations showed that centrifugation, i.e., separation due to centrifugal forces is the best way of concentrating. It facilitates removal of the maximum amount of liquid from the microalgae biomass. The resulting thick paste was lyophilized, as this type of drying allowed us to obtain biomass with dry porous structure, Figure 3.

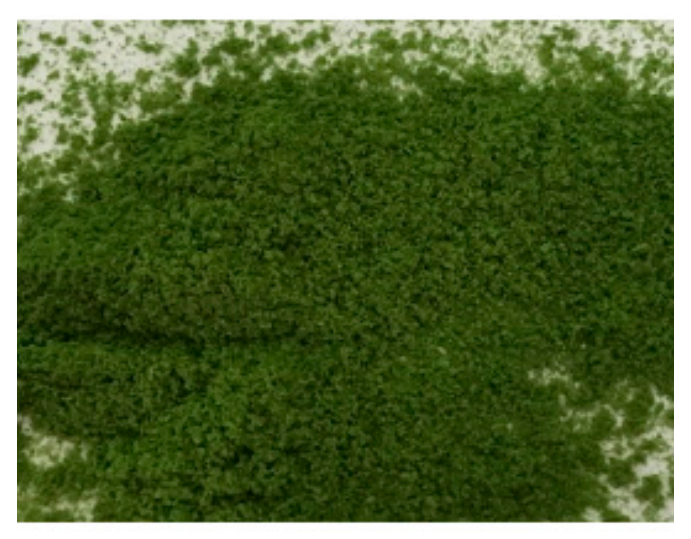

(a)

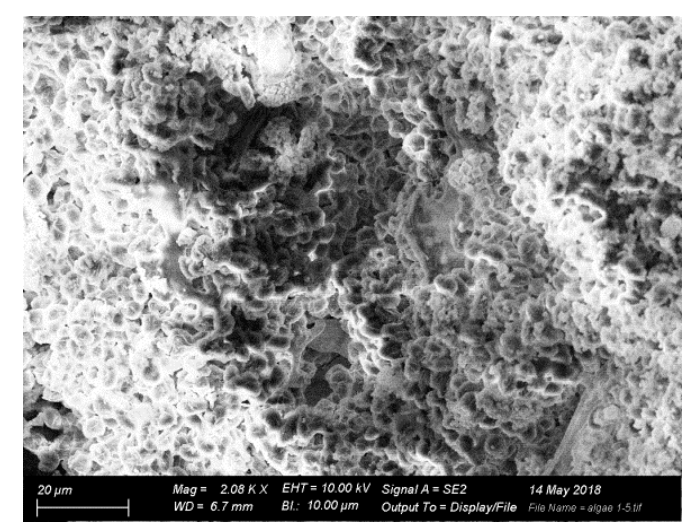

(b)

Figure 3. Surface microstructure of C. sorokiniana biomass after lyophilization: (a) external view; (b) microstructure.

To determine the presence of functional groups, the IR spectra of the obtained microalgae biomass were recorded (Figure 4).

Table 1 describes the characteristics of the spectrum. 


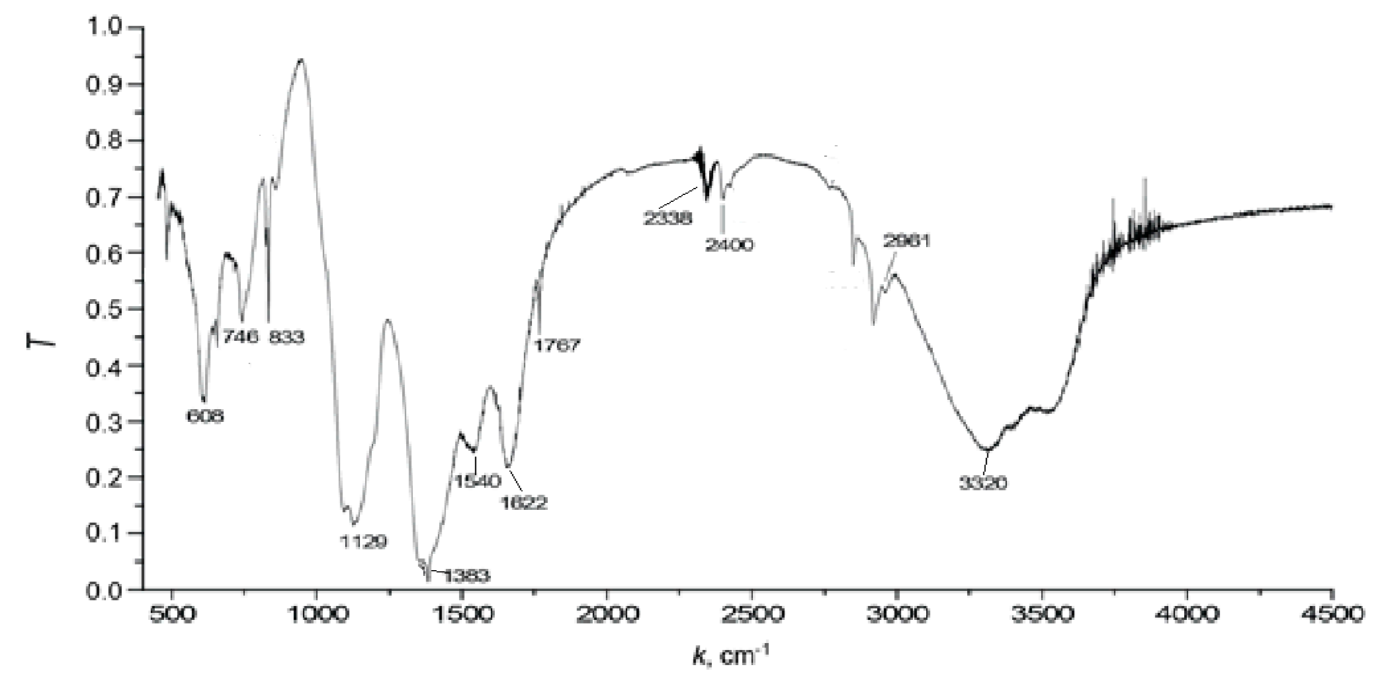

Figure 4. IR spectra of $C$. sorokiniana biomass.

Table 1. Spectral characteristic of C. sorokiniana biomass [59].

\begin{tabular}{cc}
\hline Wavelength, $\mathbf{c m}^{\mathbf{- 1}}$ & Functional Groups \\
\hline $1000-1100$ & Oxygen-containing C-O bond groups \\
\hline $1300-1400$ & Deformation vibration of NH-groups \\
\hline 1600 & Carboxyl groups $\mathrm{C}=\mathrm{O}$, \\
\hline $2800-2900$ & Asymmetric bonds of $\mathrm{CH}_{2}$ groups \\
\hline $3100-3600$ & Valence vibrations of $\mathrm{OH}$ groups \\
\hline
\end{tabular}

A wide peak at $3100-3600 \mathrm{~cm}^{-1}$ was detected, which can be considered belonging to a hydroxyl $(\mathrm{O}-\mathrm{H})$ group, responsible for the formation of hydrogen bonds. Peaks in the $2800-2900 \mathrm{~cm}^{-1}$ range are due to asymmetric stretching of $\mathrm{CH}_{2}$ groups of alkanes. The peak at $1622 \mathrm{~cm}^{-1}$ can be attributed to the $\mathrm{C}=\mathrm{O}$ carboxy stretching, which can correspond to various acids, aldehydes and ketones, which are usually formed during the degradation of cellulose and hemicellulose. A relatively sharp peak at $1000-1100 \mathrm{~cm}^{-1}$ is governed by $\mathrm{C}-\mathrm{O}$ stretching of various oxygen-containing compounds. The presence of the detected groups in the obtained biomass suggests the possibility of a chemisorption mechanism for the extraction of PTE from solutions, due to cation exchange according to the scheme: $\mathrm{zR} \cdot \mathrm{OH}+\mathrm{Me}$ $+\mathrm{z}=\mathrm{zR} \cdot \mathrm{OMe}+\mathrm{zH}_{2} \mathrm{O}$.

The resulting biomass, i.e., biosorbent, was investigated for the ability to sorb PTE from model wastewater. We have constructed adsorption isotherms of PTE (Cu (II), Cd (II), Zn (II)) by biosorbents (microalgae biomass) and calculated respective maximum sorption capacities. The maximum sorption capacity (A, mg/g) was determined, which decreases in the following order: $\mathrm{Cu}$ (II) $54.2<\mathrm{Cd}$ (II) $88.7<\mathrm{Zn}$ (II) 98.5. From the obtained data we can see that the microalgae biomass has high sorption properties and can be used as a biosorbent.

It is known from [41] that microalgae contain a large amount of fatty acids and act as sources of biofuel and Omega-3. We proposed to obtain not only lipids for Omega-3 and biodiesel, but also to use residual biomass to obtain sorbents for water purification from PTE and REM.

The obtained lipids from the biomass of C. Sorokiniana were studied by thin-layer chromatography based on the chromatographic mobility of substances Rf, identified in Figure 5:

- $\quad$ Sterols $\mathrm{Rf}=0.19$;

- $\quad$ Fatty acids $\mathrm{Rf}=0.39$;

- $\quad$ Triglycerides $\mathrm{Rf}=0.60$;

- $\quad$ Long-chain aldehydes $\mathrm{Rf}=0.73$. 


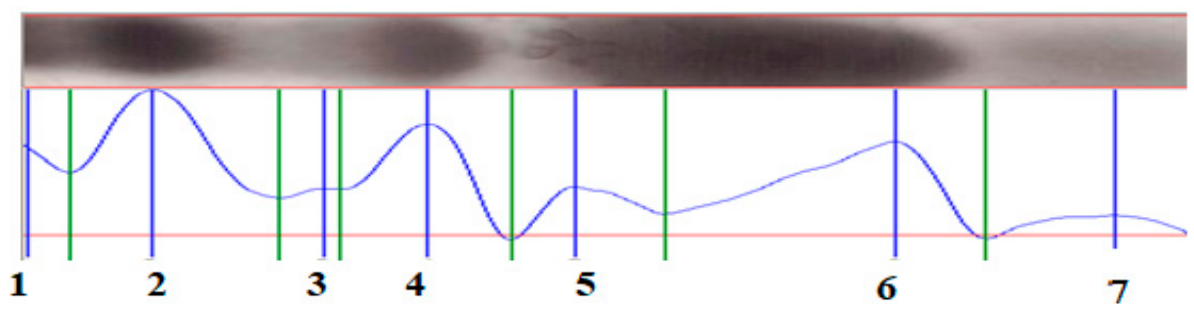

(a)

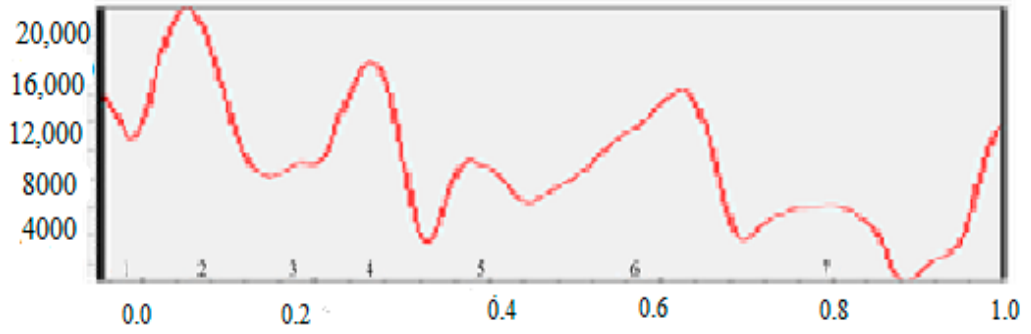

(b)

Figure 5. Chromatograms: (a) chromatographic plate view with eluent distribution, (b) chromatogram of lipid classes of C. Sorokiniana microalgae biomass

Fatty acids were studied by gas chromatography. This analysis showed that the composition of lipids is $80.02 \%$ unsaturated fatty acids (C18:1, C18:2, C18:3) and 19.98\% saturated acids with the number of carbon atoms in the chain from 16 to 20 (Figure 6, Table 2). Among unsaturated fatty acids, $\alpha$-linolenic acid was detected in the amount of $44.01 \%$ (Table 1 ) of the lipid, which belongs to the family of polyunsaturated (Omega-3) fatty acids. It regulates fat metabolism and vital activity of beneficial bacteria that live in the human intestines. It improves vision, relieves inflammation in the joints, improves brain function, provides immune system reinforcement, and helps to treat skin diseases, eczema, allergies and Alzheimer's disease. It should be noted that Omega-3 acids are not synthesized in the human body and enter it exclusively with certain foods (fatty fish, vegetable oils). In this regard, the solution to the issue of technological production of Omega-3 from C. sorokiniana microalgae seems to be quite reasonable from the standpoints of economy and affordability. Therefore, it is recommended to fractionate the obtained extract into unsaturated fatty acids that are part of Omega-3, and use the remaining fraction as biodiesel [60-62].

Table 2. Fatty acid composition of lipids derived from C. sorokiniana biomass.

\begin{tabular}{lcc}
\hline $\mathbf{N}_{\mathbf{0}}$ & Component & Percentage, wt $\%$ \\
\hline 1 & C16 Palmitic & 14.74 \\
\hline 2 & C16:1 Palmitoleic & 1.37 \\
\hline 3 & C17 Heptadecanoic & 2.69 \\
\hline 4 & C 17:1 Heptadecenoic & 0.45 \\
\hline 5 & C 18:1 n9 cis Oleinic & 18.90 \\
\hline 6 & C18-2- n6 trans $\gamma$-Linolenic & 2.90 \\
\hline 7 & C18-2 n6-cis Linolenic & 7.34 \\
\hline 8 & C18:3 n6 Linolenic & 6.88 \\
\hline 9 & C18:3 n3 $\alpha$-Linolenic & 44.01 \\
\hline 10 & C20:3 Eicosatrienoic & 0.41 \\
\hline 13 & C22 Behenic & 0.31 \\
\hline
\end{tabular}




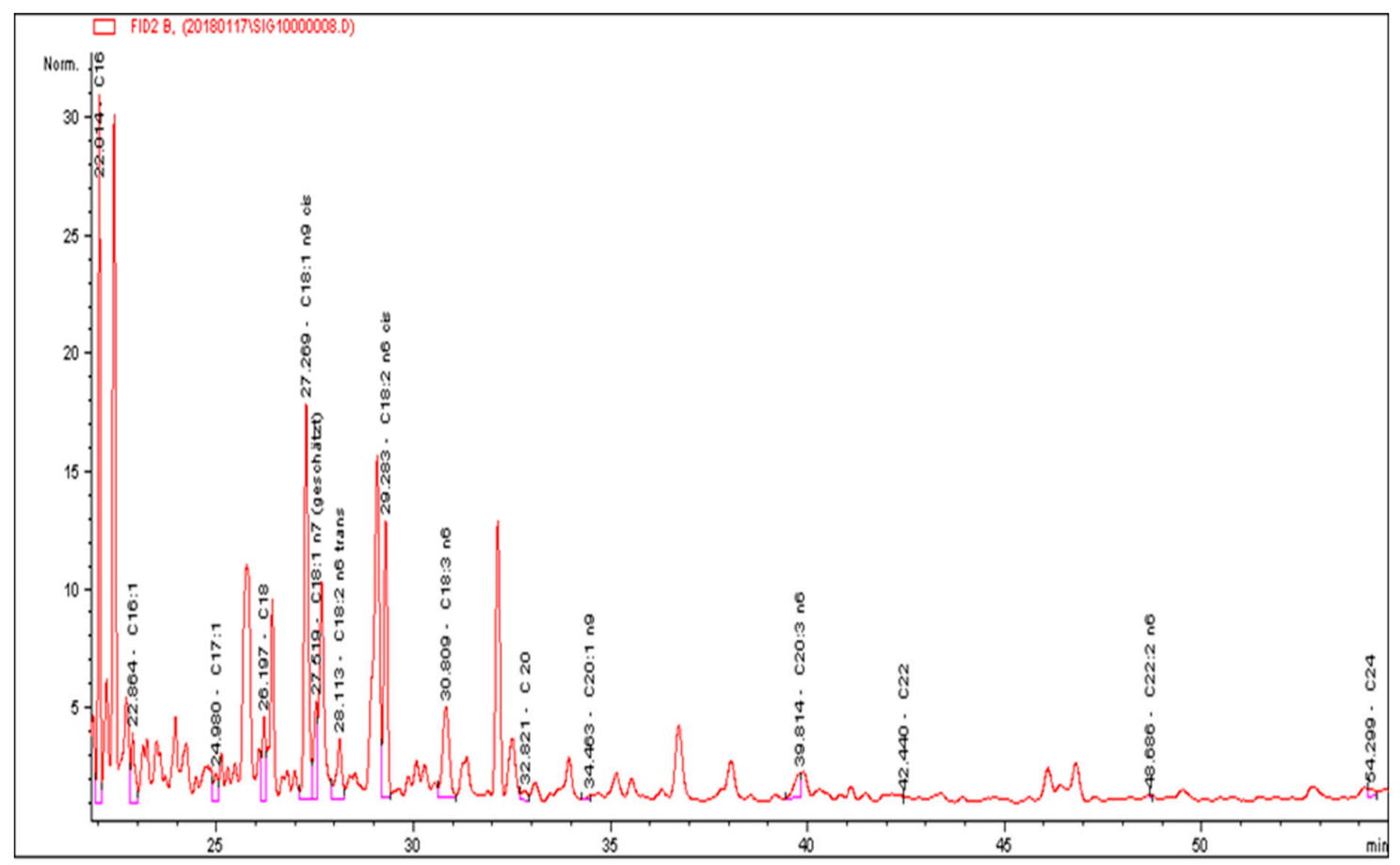

Figure 6. Chromatogram of total lipids obtained from C. sorokiniana microalgae biomass.

The resulting waste (residual biomass) after extraction is a light-gray powder (Figure 7, sorbent 1 ), consisting mainly of lignin and cellulose. To increase the sorption capacity, the residual biomass was subjected to heat treatment [56] (Figure 7, sorbent 2). The microstructural analysis showed the presence of a mesoporous surface from 0.5 to 2 microns and tubular pores (Figure 8).

It is technically difficult to use powdered thermally-treated residual biomass for wastewater treatment, because small particles are carried away with water. To increase the mechanical strength and usability, granular sorption materials were fabricated (Figure 8, sorbent 3 ).

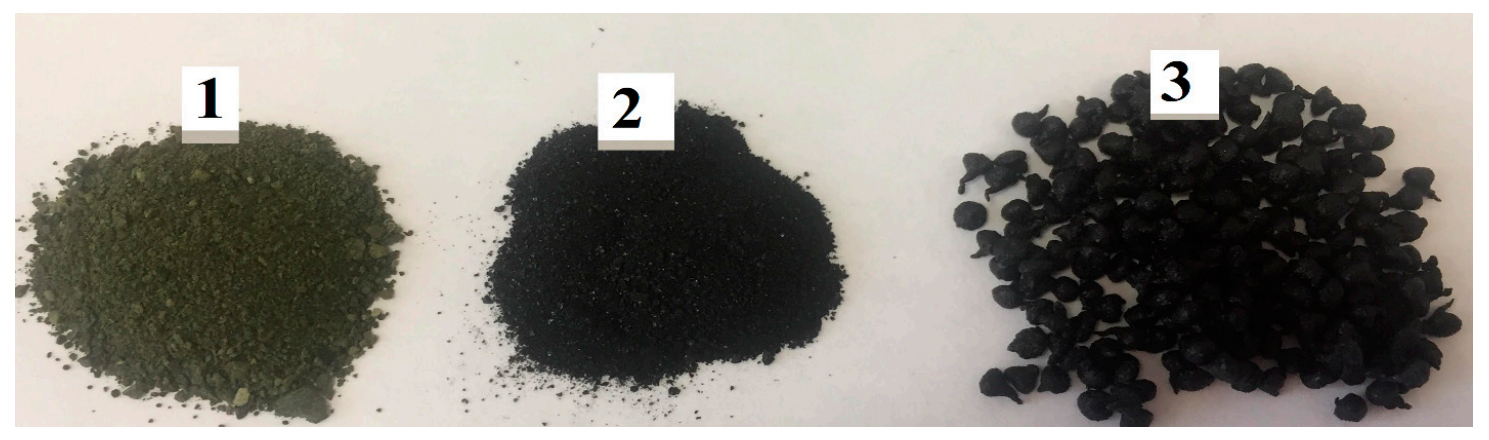

Figure 7. External view of: 1-residual biomass of microalgae C. sorokiniana; 2-thermally-treated residual biomass of microalgae C. sorokiniana; 3-granular thermally-treated residual biomass of microalgae C. sorokiniana with chitosan. 


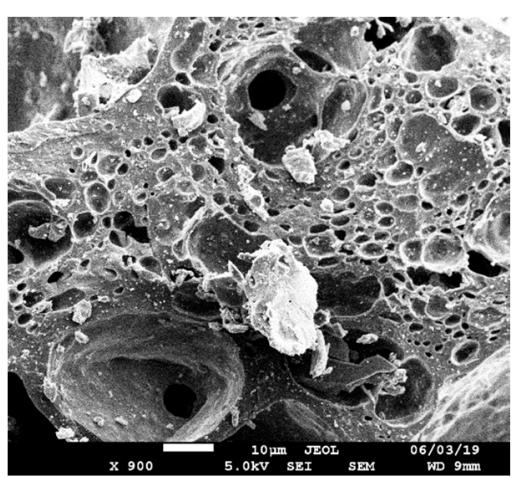

(a)

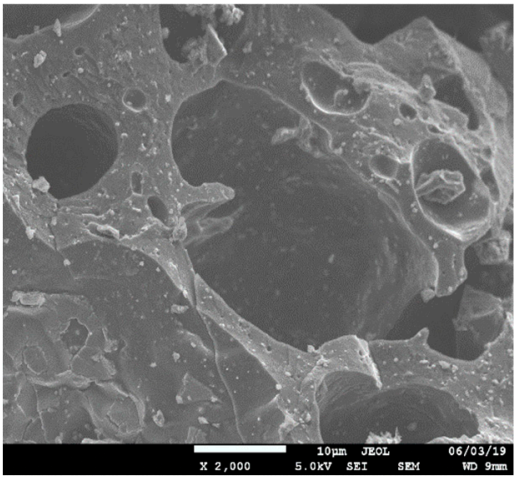

(b)

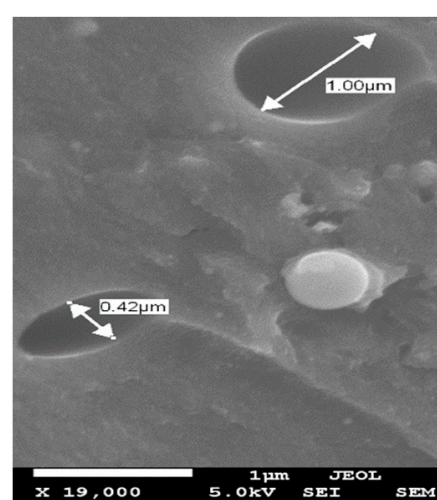

(c)

Figure 8. Surface morphology of the thermally-treated residual biomass of C. sorokiniana microalgae. expansion: (a) $\times$ 900, (b) $\times 2,000,(\mathbf{c}) \times 19,000$

The obtained materials were examined for the ability to sorb PTE and REM from model wastewater. The maximum sorption capacity for PTE $(\mathrm{Zn}+2, \mathrm{Cd}+2, \mathrm{Cu}+2)$ was calculated. Using the BET method, the specific surface of sorption materials and pore volume were calculated, Table 3.

Table 3. The maximum sorption capacity for sorbents made of residual biomass of C. sorokiniana microalgae and chitosan.

\begin{tabular}{|c|c|c|c|c|c|c|c|c|}
\hline \multirow[b]{2}{*}{ Sorbent } & \multicolumn{4}{|c|}{ Sorption Capacity, A, mg/g } & \multirow{2}{*}{$\begin{array}{c}\text { Specific } \\
\text { Surface } \\
\mathrm{m}^{2} / \mathrm{g}\end{array}$} & \multirow{2}{*}{$\begin{array}{c}\text { Pore } \\
\text { Volume, } \\
\mathrm{cm}^{3} / \mathrm{g}\end{array}$} & \multirow{2}{*}{$\begin{array}{l}\text { Average } \\
\text { Pore } \\
\text { Size, nm }\end{array}$} & \multirow{2}{*}{$\begin{array}{c}\text { Attrition, } \% \\
\text { Not More } \\
\text { Than } 0.5 \%\end{array}$} \\
\hline & $\mathrm{Zn}^{2+}$ & $\mathrm{Cd}^{2+}$ & $\mathrm{Cu}^{2+}$ & $\begin{array}{c}\text { Total A, } \\
\mathrm{mg} / \mathrm{g}\end{array}$ & & & & \\
\hline 1 & 102.5 & 62.7 & 51.2 & 216.4 & 75.5 & 0.012 & $4-6$ & - \\
\hline 2 & 132.6 & 68.3 & 54.5 & 255.4 & 28.7 & 0.098 & 5-20 & - \\
\hline 3 & 177.3 & 73.9 & 98.5 & 349.7 & 5.2 & 0.014 & $2-8$ & 0.3 \\
\hline
\end{tabular}

Table 3 shows that the total sorption capacity increases and reaches $349 \mathrm{mg} / \mathrm{g}$ when the residual biomass is thermally-treated and chitosan is added for granulation. Extraction of metal ions by residual biomass occurs due to chemisorption processes. When using thermally-treated residual biomass, it occurs due to adsorption processes (physical sorption) into the pores of the adsorbent. In case of granulated materials, the metal extraction occurs due to two sorption processes, namely chemisorption (due to the participation of functional groups of the chitosan structure) and adsorption (due to the porous surface). The sorption capacity of pure chitosan ranges between 95-225 mg/g [57,58]. The granulated sorbent from thermally-treated residual biomass and chitosan (sorbent No. 3) has the maximum sorption capacity and mechanical strength. Therefore, the sorption properties of sorbent No. 3 with respect to rare-earth metal ions were further investigated. Sorption isotherms were constructed for each metal separately. All isotherms are of the first type according to the Smith and Langmuir classification (Figure 9). The maximum adsorption capacities and Langmuir and Freundlich coefficients were calculated from isotherms (Table 4). 


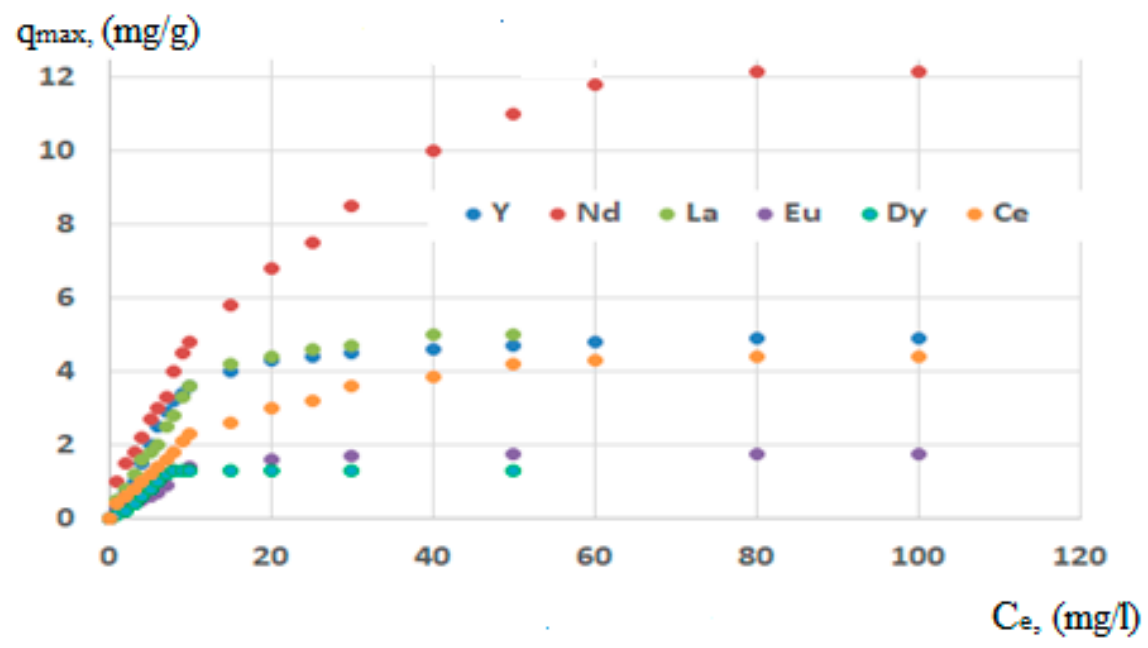

Figure 9. Isotherm of rare-earth metals (REM) adsorption from model solutions at $\mathrm{pH}=4$, sorbent No. 3.

Table 4. Maximum sorption capacity, coefficients of Langmuir and Freundlich adsorption isotherms for rare-earth metals by sorbent No. 3 , at $\mathrm{pH}=4$.

\begin{tabular}{cccccc}
\hline \multirow{2}{*}{ Elements } & \multicolumn{2}{c}{ Langmuir } & \multicolumn{3}{c}{ Freundlich } \\
\cline { 2 - 6 } & $\mathbf{q}_{\max }(\mathbf{m g} / \mathbf{g})$ & $\mathbf{R}^{\mathbf{2}}$ & $\mathbf{1 / n}$ & $\mathbf{K}_{\mathbf{F}}$ & $\mathbf{R}^{\mathbf{2}}$ \\
\hline Ce (Cerium) & 4.41 & 0.996 & 0.22 & 1.76 & 0.939 \\
Dy (Dysprosium) & 1.33 & 0.996 & 0.35 & 0.72 & 0.840 \\
Eu (Europium) & 1.74 & 0.991 & 0.33 & 0.94 & 0.920 \\
La (Lanthanum) & 5.02 & 0.999 & 0.31 & 2.03 & 0,928 \\
Y (Yttrium) & 4.85 & 0.999 & 0.30 & 1.74 & 0.880 \\
Nd (Neodymium) & 12.18 & 0.997 & 0.27 & 3.41 & 0.875 \\
Calculated $\sum$ qmax (mg/g) & \multicolumn{3}{c}{31.9} \\
\hline
\end{tabular}

From Table 3 we can see that the correlation coefficients $\mathrm{R}^{2}$ for both models of the isotherm are quite high. The Langmuir adsorption model is very well suited for calculating the maximum adsorption capacity. The $1 / \mathrm{n}$ values, which indicate the strength of adsorption, were $0.4,0.44$, and 0.48 , therefore, the sorption process is advantageous. The values of $1 / \mathrm{n}$ between 0.1 and $1 \mathrm{imply}$ successful adsorption [63]. The maximum total sorption capacity was $31.9 \mathrm{mg} / \mathrm{g}$.

After extraction of PTE and REM ions, the problem of disposal of spent sorbents arises. For the disposal of spent sorbents, we suggest using them as additional fuel for combustion systems, as an additive to fossil fuels, etc. The calorimetric method was used to determine the higher heating value of spent sorbents, which amounted to $20.7 \mathrm{MJ}^{*} \mathrm{~kg}^{-1}$. When comparing this value with classical energy carriers (Figure 10), it was shown that sorbents from residual biomass have properties that are just as good as those of the classical fuel types (stone and brown coal). As a result of the analysis, it is possible to recommend using spent sorbents as additional fuel [64]. 


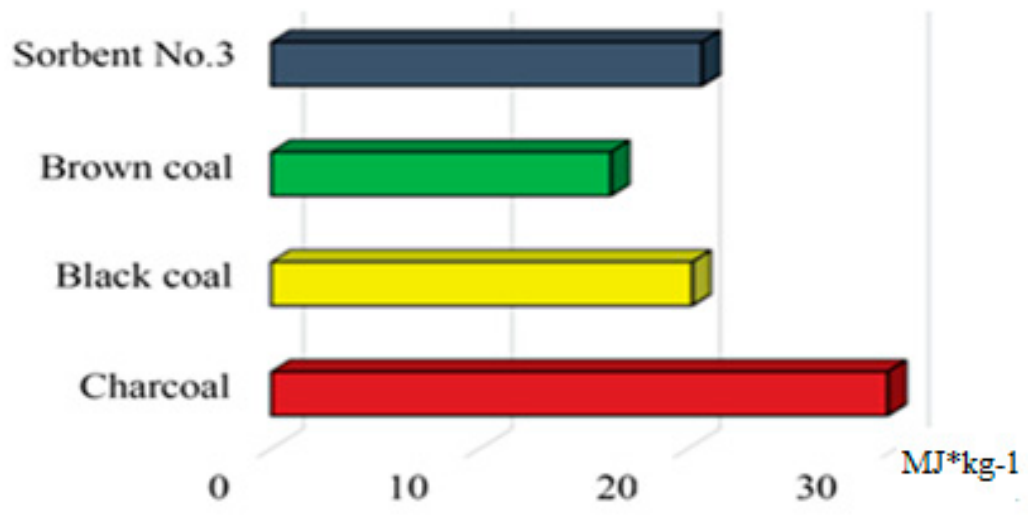

Figure 10. Specific combustion heat depending on the fuel type.

After combustion, ash contains heavy and rare-earth elements that, when separated, can be used economically, thereby solving the problem of biomining and closed-cycle zero-waste production, as shown in Figure 11.

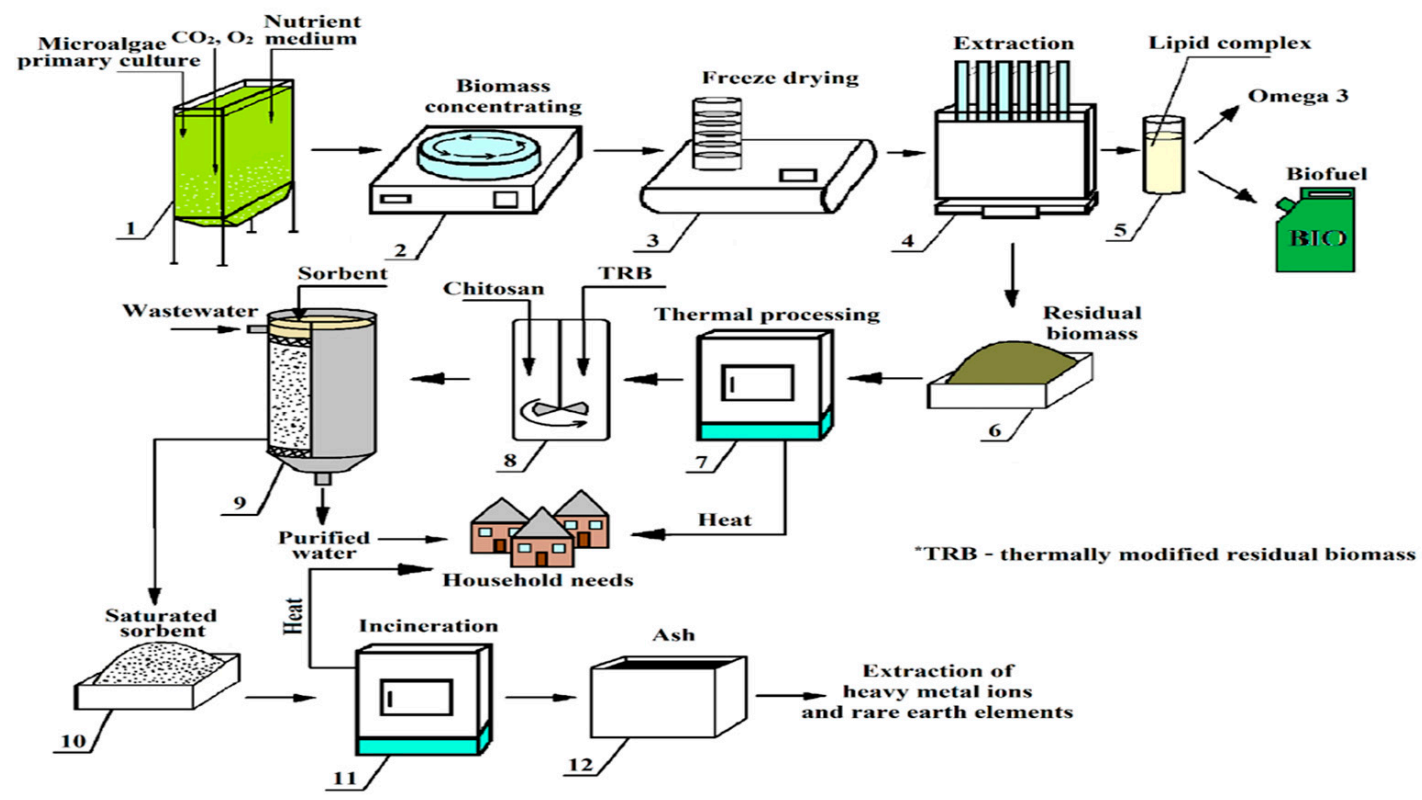

Figure 11. Closed cycle of microalgae biomass utilization with obtained products: 1 -photobioreactor; 2-centrifuge; 3-extractor; 4-lipid tank; 5-lipid tank; 6-residual biomass tank; 7-oven for thermal processing of residual biomass; 8-granulator for sorbent obtaining; 9-adsorber for water purification; 10—spent sorbent; 11 -oven for incineration of spent waste; 12 -ash tank.

This scheme of microalgae biomass multifunctional use allows for obtaining a variety of Omega-3 materials for food purposes, biofuels and sorbents for environmental purposes and finally, heat for industry or residential heat-grids, or production of combined heat and power.

\section{Conclusions}

As a result of the work done, it was proven that microalgae biomass can be used to produce lipids and sorbents. The maximum yield of lipids from biomass was $20 \%$. They contain unsaturated fatty acids, so we recommend using them for production of Omega-3, and the remaining lipid fractions for biofuels production.

The sorption properties of residual biomass were studied and a thermal modification was proposed that increases the total sorption capacity $(\mathrm{Zn}+2, \mathrm{Cd}+2, \mathrm{Cu}+2)$ from $216.4 \mathrm{mg} / \mathrm{g}$ to $255.4 \mathrm{mg} / \mathrm{g}$. 
Using chitosan as a binder of granular heat-treated residual biomass contributed to an increase in the total metal ions absorption capacity $(\mathrm{Zn}+2, \mathrm{Cd}+2, \mathrm{Cu}+2)$ up to $349.7 \mathrm{mg} / \mathrm{g}$. We have proved that granular sorbents can recover rare-earth metals with a common sorption capacity of $31 \mathrm{mg} / \mathrm{g}$. This allows us to recommend developed materials for water purification from PTE and REM.

The spent sorbents have a specific heat of combustion of $20.674 \mathrm{MJ}^{*} \mathrm{~g}^{-1}$, which is not worse than that of some classical types of fuel. Therefore, we recommend using them as fuel.

The proposed technologies for the cascade processing of microalgae biomass make it possible to obtain several useful products (lipids, sorbents, fuel) without waste generation, which corresponds to the global environmental concept.

Author Contributions: Conceptualization N.P.; methodology, Y.S.; software, Y.S.; validation, Y.S., N.P.; formal analysis, C.P.; investigation Y.S.; resources Y.S.; data curation R.A.A.; writing-original draft preparation N.P.; writing-review and editing C.P.; visualization R.A.A; supervision N.P.; project administration N.P.; funding acquisition L.M. All authors have read and agreed to the published version of the manuscript.

Funding: This research received no external funding.

Conflicts of Interest: The authors declare no conflict of interest.

\section{References}

1. Akubude, V.C.; Nwaigwe, K.N.; Dintwa, E. Production of biodiesel from microalgae via nanocatalyzed transesterification process: A review. Mater. Sci. Energy Technol. 2019, 2, 216-225. [CrossRef]

2. Rezania, S.; Oryani, B.; Park, J.; Hashemi, B.; Yadav, K.K.; Kwon, E.E.; Hur, J.; Cho, J. Review on transesterification of non-edible sources for biodiesel production with a focus on economic aspects, fuel properties and by-product applications. Energy Convers. Manag. 2019, 201, 112155. [CrossRef]

3. Al Afif, R.; Linke, B. Biogas production from three-phase olive mill solid waste in lab-scale continuously stirred tank reactor. Energy 2019, 171, 1046-1052. [CrossRef]

4. Pramanik, S.K.; Suja, F.B.; Zain, S.; Pramanik, B.K. The anaerobic digestion process of biogas production from food waste: Prospects and constraints. Bioresour. Technol. Rep. 2019, 8, 100310. [CrossRef]

5. Al Afif, R.; Amon, T. Mesophilic anaerobic co-digestion of cow manure with three-phase olive mill solid waste. Energy Sources Part A Recovery Util. Environ. Eff. 2018. [CrossRef]

6. Rasapoor, M.; Young, B.; Brar, R.; Sarmah, A.; Zhuang, W.Q.; Baroutian, S. Recognizing the challenges of anaerobic digestion: Critical steps toward improving biogas generation. Fuel 2020, 261, 116497. [CrossRef]

7. Sun, X.; Atiyeh, H.K.; Huhnke, R.L.; Tanner, R.S. Syngas fermentation process development for production of biofuels and chemicals: A review. Bioresour. Technol. Rep. 2019, 7, 100279. [CrossRef]

8. Al Afif, R.; Wendland, M.; Amon, T.; Pfeifer, C. Supercritical carbon dioxide enhanced pre-treatment of cotton stalks for methane production. Energy 2020, 194. [CrossRef]

9. Li, P.; Sakuragi, K.; Makino, H. Extraction techniques in sustainable biofuel production: A concise review. Fuel Process. Technol. 2019, 193, 295-303. [CrossRef]

10. Shen, Y. A review on hydrothermal carbonization of biomass and plastic wastes to energy products. Biomass Bioenergy 2020, 134, 105479. [CrossRef]

11. Sharma, H.B.; Sarmah, A.K.; Dubey, B. Hydrothermal carbonization of renewable waste biomass for solid biofuel production: A discussion on process mechanism, the influence of process parameters, environmental performance and fuel properties of hydrochar. Renew. Sustain. Energy Rev. 2020, 123, 109761. [CrossRef]

12. Seyedsadr, S.; Al Afif, R.; Pfeifer, C. Hydrothermal carbonization of agricultural residues: A case study of the farm residues -based biogas plants. Carbon Resour. Convers. 2018, 1, 81-85. [CrossRef]

13. Wang, L.; Chang, Y.; Li, A. Hydrothermal carbonization for energy-efficient processing of sewage sludge: A review. Renew. Sustain. Energy Rev. 2019, 108, 423-440. [CrossRef]

14. Uzoejinwa, B.B.; He, X.; Wang, S.; Abomohra, A.; Hu, Y.; Wang, Q. Co-pyrolysis of biomass and waste plastics as a thermochemical conversion technology for high-grade biofuel production: Recent progress and future directions elsewhere worldwide. Energy Convers. Manag. 2018, 163, 468-492. [CrossRef]

15. Al Afif, R.; Anayah, S.; Pfeifer, P. Batch pyrolysis of cotton stalks for evaluation of biochar energy potential. Renew. Energy 2020, 147, 2250-2258. [CrossRef] 
16. Al Afif, R.; Pfeifer, C.; Pröll, T. Bioenergy recovery from cotton stalk. In Cotton Research; IntechOpen: London, UK, 2019. [CrossRef]

17. Schaffer, S.; Pröll, T.; Al Afif, R.; Pfeifer, C. A mass- and energy balance-based process modelling study for the pyrolysis of cotton stalks with char utilization for sustainable soil enhancement and carbon storage. Biomass Bioenergy 2019, 120, 281-290. [CrossRef]

18. Pröll, T.; Al Afif, R.; Schaffer, S.; Pfeifer, C. Reduced local emissions and long-term carbon storage through pyrolysis of agricultural waste and application of pyrolysis char for soil improvement. Energy Procedia 2017, 114, 6057-6066. [CrossRef]

19. Yang, C.; Li, R.; Zhang, B.; Qiu, Q.; Wang, B.; Yang, H.; Ding, Y.; Wang, C. Pyrolysis of microalgae: A critical review. Fuel Process. Technol. 2019, 186, 53-72. [CrossRef]

20. Vineet Sing, S.; Ming, Z.; Fennel, P.S.; Shah, N.; Anthony, E.J. Progress in biofuel production from gasification. Prog. Energy Combust. Sci. 2017, 61, 189-248. [CrossRef]

21. Widjaya, E.R.; Chen, G.; Bowtell, L.; Hills, C. Gasification of non-woody biomass: A literature review. Renew. Sustain. Energy Rev. 2018, 89, 184-193. [CrossRef]

22. Karl, J.; Pröll, T. Steam gasification of biomass in dual fluidized bed gasifiers: A review. Renew. Sustain. Energy Rev. 2018, 98, 64-78. [CrossRef]

23. Sansaniwal, S.K.; Rosen, M.A.; Tyagi, S.K. Global challenges in the sustainable development of biomass gasification: An overview. Renew. Sustain. Energy Rev. 2017, 80, 23-43. [CrossRef]

24. Kim, J.Y.; Lee, H.W.; Lee, S.M.; Jae, J.; Park, Y.K. Overview of the recent advances in lignocellulose liquefaction for producing biofuels, bio-based materials and chemicals. Bioresour. Technol. 2019, 279, 373-384. [CrossRef]

25. Perkins, G.; Batalha, N.; Kumar, A.; Bhaskar, T.; Konarova, M. Recent advances in liquefaction technologies for production of liquid hydrocarbon fuels from biomass and carbonaceous wastes. Renew. Sustain. Energy Rev. 2019, 115, 109400. [CrossRef]

26. Gu, X.; Martinez-Fernandez, J.S.; Pang, N.; Fu, X.; Chen, S. Recent development of hydrothermal liquefaction for algal biorefinery. Renew. Sustain. Energy Rev. 2020, 121, 109707. [CrossRef]

27. Vassilev, S.V.; Vassileva, C.G. Composition, properties and challenges of algae biomass for biofuel application: An overview. Fuel 2016, 181, 1-33. [CrossRef]

28. Mathimani, T.; Pugazhendhi, A. Utilization of algae for biofuel, bio-products and bio-remediation. Biocatal. Agric. Biotechnol. 2019, 17, 326-330. [CrossRef]

29. Pragya, N.; Pandey, K.K.; Sahoo, P.K. A review on harvesting, oil extraction and biofuels production technologies from microalgae. Renew. Sustain. Energy Rev. 2013, 24, 159-171. [CrossRef]

30. Lee, X.J.; Ong, H.C.; Gan, Y.Y.; Chen, W.H.; Mahlia, T.M.I. State of art review on conventional and advanced pyrolysis of macroalgae and microalgae for biochar, bio-oil and bio-syngas production. Energy Convers. Manag. 2020, 210, 112707. [CrossRef]

31. Mandika, I.; Cheirsilp, B.; Srinuanpan, S.; Maneechote, W.; Boonsawang, P.; Prasertsan, P.; Sirisansaneeyakuld, S. Zero-waste biorefinery of oleaginous microalgae as promising sources of biofuels and biochemicals through direct transesterification and acid hydrolysis. Process Biochem. 2020. [CrossRef]

32. Chew, K.W.; Yap, J.Y.; Show, P.L.; Suan, N.H.; Juan, J.C.; Ling, T.C.; Lee, D.-J.; Chang, J.-S. Microalgae biorefinery: High value products perspectives. Bioresour. Technol. 2017, 229, 53-62. [CrossRef] [PubMed]

33. Venugopal, V. Functional Foods and Nutraceuticals: Marine Products for Healthcare: Functional and Bioactive Nutraceutical Compounds from the Ocean; CRC Press: Boca Raton, FL, USA, 2008; p. 528.

34. Kotrbáček, V.; Doubek, J.; Doucha, J. The chlorococcalean alga Chlorella in animal nutrition: a review. J Appl Psychol. 2015, 27, 2173-2180.

35. Kunitsyn, M.V. Utilization of a Suspension of Planktonic Strain of Chlorella as a Dietary Supplement to Food. RU Patent 2013112810A, 20 May 2015.

36. Posten, C.; Walter, C. Microalgal Biotechnology: Integration and Economy. Available online: https: //www.degruyter.com/view/title/125819 (accessed on 14 March 2020).

37. Richman, A. The new age of Marine Nutraceuticals. Nutraceuticals World 2013, 16, 40-48.

38. Wong, K.H.; Cheung, P.C.K. Nutritional evaluation of some subtropical red and green seaweeds: Part I-Proximate composition, amino acid profiles and some physico-chemical properties. Food Chem. 2000, 71, 475-482. [CrossRef] 
39. Politaeva, N.A.; Smyatskaya, Y.u.A.; Kuznetsova, T.A.; Olshanskaya, L.N.; Valiev, R.S.h. Cultivation and Use of Chlorella Microalgae and Higher Aquatic Plant Lemna Duckweed; Nauka: Saratov, Russia, 2017; p. 125. ISBN 978-5-9999-2883-2. (In Russian)

40. Menegazzo, M.L. Fonseca G.G., Biomass recovery and lipid extraction processes for microalgae biofuels production: A review. Renew. Sustain. Energy Rev. 2019, 107, 87-107. [CrossRef]

41. Kobayashi, N.; Noel, E.A.; Barnes, A.; Watson, A.; Rosenberg, J.N.; Erickson, G.; Oyler, G.A. Characterization of three Chlorella sorokiniana strains in anaerobic digested effluent from cattle manure. Bioresour. Technol. 2013, 150, 377-386. [CrossRef] [PubMed]

42. Chader, S.; Mahmah, B.; Chetehouna, K.; Mignolet, E. Biodiesel production using Chlorella sorokiniana a green microalga. Rev. Energies Renouv. 2011, 14, 21-26.

43. Blinová, L.; Bartošová, A.; Gerulová Blinová, K. Cultivation of microalgae (Chlorella vulgaris) for biodiesel production. Res. Pap. Fac. Mater. Sci. Technol. Slovak Univ. Technol. 2015, 23, 87-95. [CrossRef]

44. Işıldar, A.; van Hullebusch, E.D.; Lenz, M.; Du Laing, G.; Marra, A.; Cesaro, A.; Panda, S.; Akcil, A.; Kucuker, M.A.; Kuchta, K. Biotechnological strategies for the recovery of valuable and critical raw materials from waste electrical and electronic equipment (WEEE)—A review. J. Hazard. Mater. 2018. [CrossRef]

45. Johnson, D.B. Biomining-biotechnologies for extracting and recovering metals from ores and waste materials. Curr. Opin. Biotechnol. 2014, 30, 24-31. [CrossRef]

46. Brierley, C.L.; Brierley, J.A. Progress in bioleaching: Part B: Applications of microbial processes by the minerals industries. Appl. Microbiol. Biotechnol. 2013, 97, 7543-7552. [CrossRef] [PubMed]

47. Kucuker, M.A.; Kuchta, K. Biomining-Biotechnological Systems (Bioleaching and Biosorption) for the Extraction and Recovery of Metals from Secondary Sources. Glob. Nest J. 2017, 20, 28-33.

48. Farooq, U.; Kozinski, J.A.; Khan, M.A.; Athar, M. Biosorption of heavy metal ions using wheat based biosorbents-A review of the recent literature. Bioresour. Technol. 2010, 101, 5043-5053. [CrossRef]

49. Dhankhar, R.; Hooda, A. Fungal biosorption-An alternative to meet the challenges of heavy metal pollution in aqueous solutions. Environ. Technol. 2011, 32, 467-491. [CrossRef] [PubMed]

50. Dave, S.R.; Sodha, A.B.; Tipre, D.R. Microbial technology for metal recovery from e-waste printed circuit boards. J. Bacteriol. Mycol. 2018, 6, 241-247. [CrossRef]

51. Kucuker, M.A.; Wieczorek, N.; Kuchta, K.; Copty, N.K. Biosorption of neodymium on Chlorella vulgaris in aqueous solution obtained from hard disk drive magnets. PLoS ONE 2017, 12, e0175255. [CrossRef] [PubMed]

52. Petrovič, A.; Simonič, M. Removal of heavy metal ions from drinking water by alginate-immobilised Chlorella sorokiniana. Int. J. Environ. Sci. Technol. 2016, 13, 1761-1780. [CrossRef]

53. Akhtar, N.; Iqbal, M.; Zafar, S.I.; Iqbal, J. Biosorption characteristics of unicellular green alga Chlorella sorokiniana immobilized in loofa sponge for removal of Cr(III). J. Environ. Sci. 2008, 20, 231-239. [CrossRef]

54. Ardila, L.; Godoy, R.; Montenegro, L. Sorption capacity measurement of Chlorella vulgaris and Scenedesmus acutus to remove chromium from tannery waste water. IOP Conf. Ser. Earth Environ. Sci. 2017, 83, 1-16. [CrossRef]

55. Zhou, W.; Cheng, Y.; Li, Y.; Wan, Y.; Liu, Y.; Lin, X.; Ruan, R. Novel fungal pelletization-assisted technology for algae harvesting and wastewater treatmen. Appl. Biochem. Biotechnol. 2012, 167, 214-228. [CrossRef]

56. Sobgaida, N.A.; Olshanskaya, L.N.; Makarova, Y.u.A. The effect of wheat husk modification on its sorption properties to $\mathrm{Pb}^{2+}, \mathrm{Cd}^{2+}, \mathrm{Zn}^{2+}$ and $\mathrm{Cu}^{2+}$ ions. Izv. Vyss. Uchebnykh Zaved. Seriya Khimiya Khimicheskaya Tekhnologiya 2010, 53, 36-40.

57. Taranovskaya, E.A.; Sobgaida, N.A.; Markina, D.V. Technology for Obtaining and Using Granulated Absorbents Based on Chitosan. Chem. Pet. Eng. 2016, 52, 357-361. [CrossRef]

58. Politaeva, N.A.; Slugin, V.V.; Taranovskaya, E.A.; Soloviev, M.A.; Zakharevich, A.M. Granulated sorption materials for waste waters purufucation from zink ions $\left(\mathrm{Zn}^{2+}\right)$. Izv. Vyss. Uchebnykh Zaved. Seriya Khimiya Khimicheskaya Tekhnologiya 2017, 60, 85-90. [CrossRef]

59. Politaeva, N.A.; Smyatskaya, Y.A.; Tatarintseva, E.A. Tatarintseva Using Adsorption Material Based on the Residual Biomass of Chlorella sorokiniana Microalgae for Wastewater Purification to Remove Heavy Metal Ions. Chem. Pet. Eng. 2020, 55, 907-912. [CrossRef]

60. Adarme-Vega, T.C.; Lim, D.K.; Timmins, M.; Vernen, F.; Li, Y.; Schenk, P.M. Microalgal biofactories: A promising approach towards sustainable omega-3 fatty acid production. Microb. Cell Fact. 2012, 11, 96. [CrossRef] 
61. Simopoulos, A.P. Omega-3 fatty acids in inflammation and autoimmune diseases. J. Am. Coll. Nutr. 2002, 21, 494-505. [CrossRef] [PubMed]

62. Suliman, K.; Rabeea, S.; Wasim, S.; Ghulam, N.; Khizar, H.; Pengfei, D.; Lunguang, Y. Biodiesel Production From Algae to Overcome the Energy Crisis. HAYATI J. Biosci. 2017, 24, 163-167. [CrossRef]

63. Dada, A.O.; Olalekan, A.P.; Olatunya, A.M. Isotherm and thermodynamic studies of Cd (II) removal process using chemically modified lignocellulosic adsorbent. Appl. Chem. 2012, 3, 38-45.

64. Physical Encyclopedia. Available online: https://www.prlib.ru/en/history/619024 (accessed on 1 April 2020).

(C) 2020 by the authors. Licensee MDPI, Basel, Switzerland. This article is an open access article distributed under the terms and conditions of the Creative Commons Attribution (CC BY) license (http://creativecommons.org/licenses/by/4.0/). 